\title{
Anti-inflammatory effect of aged black garlic on 12-O-tetradecanoylphorbol-13-acetate-induced dermatitis in mice
}

\author{
Bo Ram You ${ }^{1 *}$, Jae-Myung Yoo ${ }^{2 *}$, Seong Yeon Baek ${ }^{1}$ and Mee Ree Kim ${ }^{1 \S}$ \\ 'Department of Food and Nutrition, Chungnam National University, 99 Daehak-ro, Yuseong-gu, Daejeon 34134, Korea \\ ${ }^{2}$ Korean Medicine-Application Center, Korea Institute of Oriental Medicine, Daegu 41062, Korea
}

BACKGROUND/OBJECTIVES: Although aged black garlic has various biological activities such as anti-allergy, anti-inflammation and neuroprotection, effect of aged black garlic on chemically contact dermatitis is unclarified.

MATERIALS/METHODS: To evaluate anti-dermatitic activity of aged black garlic extract, we investigated effects of a fraction of aged black garlic extract (BG10) on both in vivo and in vitro.

RESULTS: BG10 almost inhibited formation of nitric monoxide and interleukin-6 (IL-6; IC $50,7.07 \mu \mathrm{g} / \mathrm{mL}$ ) at $25 \mu \mathrm{g} / \mathrm{mL}$, and dose-dependently reduced production of tumor necrosis factor- $a$ (TNF- $\alpha$; $\mathrm{IC}_{50}, 52.07 \mu \mathrm{g} / \mathrm{mL}$ ) and prostaglandin $E_{2}\left(\mathrm{IC}_{50}, 38.46\right.$ $\mu \mathrm{g} / \mathrm{mL}$ ) in lipopolysaccharide-stimulated RAW264.7 cells. In addition, BG10 significantly inhibited the expression of inducible

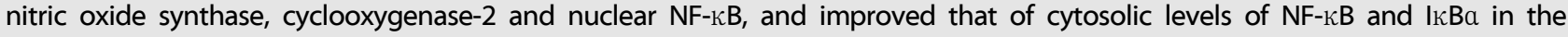
cells. Consistent with in vitro studies, BG10 $(0.5 \mathrm{mg} / \mathrm{mL})$ not only reduced ear edema but also suppressed the formation of IL-6 and TNF- $a$ induced by 12-O-tetradecanoylphorbol-13-acetate in ear tissues of mice.

CONCLUSIONS: These findings suggest BG10 has anti-dermatitic activity through inhibiting activation of macrophages. Therefore, such effects of BG10 may provide information for the application of aged black garlic for prevention and therapy of contact dermatitis.

Nutrition Research and Practice 2019;13(3):189-195; https://doi.org/10.4162/nrp.2019.13.3.189; plSSN 1976-1457 elSSN 2005-6168

Keywords: Contact dermatitis, COX-2, cytokines, macrophage, NF-kappa B

\section{INTRODUCTION}

Contact dermatitis as one of acute inflammatory diseases in skin tissues includes allergic and irritant contact dermatitis [1]. Allergic contact dermatitis affiliated with hypersensitive reaction known as a type I allergy $[2,3]$ is induced by various antigens such as foods, drugs and environmental factors [1]. The hypersensitive reaction is closely correlated with mast cells [3]. On the other hand, the initiation of irritant contact dermatitis by chemicals, such as 12-O-tetradecanoylphorbol-13-acetate (TPA), is associated with Langerhans cells and inflammatory dendritic epidermal cells [1]. The immune cells related with contact dermatitis produce inflammatory inducers such as inflammatory cytokines and eicosanoids, and then the inflammatory inducers initiate acute inflammation by recruiting various immune cells such as macrophages, monocytes and mast cells in surrounding normal tissues $[1,4]$. Especially, dermatitis bullosa belonging with contact dermatitis is involved in tissue necrosis by disruption of skin barrier [1]. If left untreated, the disease is able to progresses permanent tissue damage or septicemia. Therefore, the initial treatment or prevention of contact dermatitis is very important.

Garlic (Allium sativum) affiliated with a member of the lily family possesses beneficial effects on various biological events including anti-cancer, anti-hyperlipidemia and anti-inflammation [5-7]. Such effects are associated with different bioactive compounds such as phenolic compounds, flavonoids and organosulfur compounds $[8,9]$. However, the intake of garlic for a phytomedicine and a functional food is limited, because it has harmful effects correlated with rich organosulfides [10]. Moreover, raw garlic leads to severe contact dermatitis [11]. In contrast, aged black garlic (ABG), prepared from diverse processes [12-14], has an advantage in its beneficial effects with less side effects $[12,15-17]$. The reason is that ABG includes the elevated levels of S-allylcysteine [15] and polyphenols $[15,18]$. Recently, we found that ABG exerted anti-septic and antiallergic actions [16,17], and its fraction (BG10) had more antiallergic activity than the crude extract [16]. Nonetheless, effect of $A G B$ and $B G 10$ on contact dermatitis remains unknown.

Therefore, we were interested in effect of BG10 on contact dermatitis, after we found that $A B G$ and BG10 possessed immunomodulatory actions. In this study, we hypothesized that BG10

\footnotetext{
This work was supported by research fund of Chungnam National University.

${ }^{\S}$ Corresponding Author: Mee Ree Kim, Tel. 82-42-821-6837, FAX. 82-42-821-8671, Email. mrkim@cnu.ac.kr

Received: July 16, 2018, Revised: August 5, 2018, Accepted: February 12, 2019

* These two authors contributed equally to this study.

This is an Open Access article distributed under the terms of the Creative Commons Attribution Non-Commercial License (http://creativecommons.org/licenses/by-nc/3.0/)

which permits unrestricted non-commercial use, distribution, and reproduction in any medium, provided the original work is properly cited.
} 
could inhibit contact dermatitis through suppressing activation of immune cells such as macrophages, and then investigated anti-inflammatory actions of BG10 in both lipopolysaccharide (LPS)-activated RAW264.7 cells, a murine macrophage cell line [19], and TPA-induced contact dermatitis in mice. Herein, we showed that BG10 had anti-dermatitic actions in both in vivo and in vitro systems, and demonstrates how BG10 inhibits acute inflammatory reaction. Such effects of BG10 may provide further information for the development of a phytomedicine and a functional food for the treatment of contact dermatitis.

\section{MATERIALS AND METHODS}

\section{Reagents}

Dulbecco's modified Eagle's minimum essential medium (DMEM), $1 \times$ DPBS and $1 \times$ PBS were obtained from WelGENE (Gyeongsan, Korea). Antibiotics and fetal bovine serum (FBS) were purchased from Gibco Life Technologies (Grand Island, NY, USA). Specific antibodies against inducible nitric oxide synthase (iNOS), cyclooxygenase-2 (COX-2), nuclear factor- $\kappa \mathrm{B}$ (NF- $\kappa \mathrm{B}), \mathrm{NF}-$ $\kappa B$ inhibitor $(\kappa B)$ and Lamin $B$ were procured form Cell Signaling Technology (Beverly, MA, USA). A specific antibody against $\beta$ -actin were obtained from Santa Cruz Biotechnology, Inc. (Dallas, TX, USA). Enzyme-linked immunosorbent assay (ELISA) kit for interleukin-6 (IL-6) and tumor necrosis factor-a (TNF-a) were obtained from e-Bioscience, Inc. (Science Center Drive, San Diego, USA). Enzyme immunoassay (EIA) kit for prostaglandin $E_{2}\left(P E_{2}\right)$ was purchased from Cayman Chemical (Ann Arbor, MI, USA). Ethylenediaminetetraacetic acid (EDTA), LPS (Escherichia coli O55:B5), methyl thiazolyl tetrazolium (MTT), thiobarbituric acid (TBA), trichoroacetic acid (TCA), 1,1-Diphenyl2-picrylhydrazil (DPPH), 2,2'-azino-bis(3-ethylbenzothiazoline-6sulphonic acid (ABTS), 2-deoxy-D-ribose, Ferric-reducing antioxidant power (FRAP), vitamin $C$, and all other chemicals were obtained from Sigma-Aldrich (St Louis, MO, USA). All other chemicals were of analytical grade.

\section{Plant material and fractionation}

ABG and BG10 were prepared according to a process reported previously [16]. Homogenized ABG (2.6 kg) was extracted with $80 \%$ methanol ( $5 \mathrm{~L}$ ) in a bath sonicator for $36 \mathrm{~h}$, and then filtered by filter paper. The filtrate was evaporated, and then the residue of $A B G$ was dissolved in deionized water. The ABG solution was mixed with three volumes of ethyl acetate, and then, the layer of ethyl acetate was separated and evaporated. The dried residue of ethyl acetate extract was dissolved in methanol, and then suspended in deionized water. The mixture was loaded onto an open column $\left(C_{18}, 40-63 \mu \mathrm{m}\right)$, and then, the column was eluted by the methanol solution $(500 \mathrm{~mL}$ of each) to yield 15 fractions. BG10 fraction was evaporated. The dried residue of BG10 was dissolved in ethanol for in vitro tests, and acetone for in vivo study.

\section{Antioxidant activity assays}

\section{DPPH scavenging activity assay}

DPPH radical scavenging activity was measured according to the method reported previously [20]. BG10 $(0.1 \mathrm{mg})$ or vitamin
C $(0.05 \mathrm{mg})$ were dissolved in methanol $(1 \mathrm{~mL})$. The solution $(0.2 \mathrm{~mL})$ was mixed with $0.1 \mathrm{mM} \mathrm{DPPH}$ solution $(4 \mathrm{~mL})$, and then incubated for $30 \mathrm{~min}$ in the darkness. Its absorbance at $517 \mathrm{~nm}$ were determined using a micro-plate reader (DU650, Beckman Coulter, Inc., Brea, CA, USA).

\section{FRAP assay}

FRAP assay was determined following the method of the previous reported [20]. Briefly, diluted samples $(0.1 \mathrm{~mL})$ were mixed with $4.0 \mathrm{~mL}$ of FRAP reagent, and then incubated at $37^{\circ} \mathrm{C}$ for $10 \mathrm{~min}$ in the dark. The absorbance of final solution at 593 $\mathrm{nm}$ was measured using a micro-plate reader.

\section{ABTS radical scavenging activity assay}

ABTS radical scavenging activity assay was determined carried out the protocol of the previous reported [20]. Briefly, samples $(0.1 \mathrm{~mL})$ were added to $2.9 \mathrm{~mL}$ of diluted ABTS solution, and then incubated for $20 \mathrm{~min}$. The mixture's absorbance at 734 $\mathrm{nm}$ was measured using a micro-plate reader.

Hydroxyl radical scavenging activity assay

Hydroxyl radical scavenging activity was determined following the method reported previously [20]. Briefly, BG10 $(0.1 \mathrm{mg})$ or vitamin $C(0.05 \mathrm{mg})$ were dissolved in $1 \times$ PBS $(1 \mathrm{~mL})$. The sample solution $(0.15 \mathrm{~mL})$ was mixed with $0.2 \mathrm{~mL}$ of hydroxyl radical solution $\left(10 \mathrm{mM} \mathrm{FeSO}_{4}, 10 \mathrm{mM}\right.$ EDTA and $10 \mathrm{mM}$ 2-deoxy$D$-ribose), spiked with $10 \mathrm{mM}$ hydrogen peroxide $(0.2 \mathrm{~mL})$, and then incubated for $4 \mathrm{~h}$ at $37^{\circ} \mathrm{C}$. After incubation, the solution was mixed with $1 \mathrm{~mL}$ of $2.8 \%$ TCA and $1.0 \%$ TBA, and then heated in boiling water for $10 \mathrm{~min}$. The final reaction mixture was cooled in ice water and then centrifuged ( $800 \mathrm{~g}, 10 \mathrm{~min})$. The absorbance of supernatant at $532 \mathrm{~nm}$ was measured using a micro-plate reader.

\section{Animals}

ICR mice, known as Swiss CD-1 mice [21], (male, 6 weeks and 25-30 g) were procured from Nara Biotech Co. (Pyeongteak, Korea), and housed in cages ( 5 mice per cage) under specific pathogen-free condition $\left(21-24^{\circ} \mathrm{C}\right.$ and $40-60 \%$ relative humidity) with a $12 \mathrm{~h}$ light/dark cycle, and free access to standard rodent food (Orientbio Inc., Seongnam, Korea) and water. All animal experiments were approved by the Committee of Animal Care and Experiment of Chungnam National University, Korea (CNU-00137), and performed according to the guidelines of the Animal Care and Use Committee at Chungnam National University.

12-O-tetradecanoylphorbol-13-acetate-induced contact dermatitis

TPA-induced contact dermatitis was evaluated following the previous method [22]. After adaptation, mice were applied with BG10 $(0.5 \mathrm{mg} / \mathrm{mL})$ to the back of ears once a day. After 7 days, they were spread with TPA dissolved in acetone $(0.1 \mathrm{mg} / \mathrm{mL})$ on the ears after BG10 application. Next day, the ears were isolated from sacrificed mice after measurement of ear thickness. The ear tissues were frozen in liquid nitrogen, and then quickly pulverized. The powder of ear tissue was lysed with a lysis buffer, and then centrifuged $(15,000 \mathrm{~g}, 15 \mathrm{~min})$ at $4^{\circ} \mathrm{C}$. The lysates were stored at $-80^{\circ} \mathrm{C}$ until use. 


\section{Cell culture}

RAW264.7 cells were procured form the Korean Cell Line Bank (Seoul, Korea). The cells were cultured in DMEM medium containing 10\% (v/v) FBS, 100 units $/ \mathrm{mL}$ penicillin and $100 \mu \mathrm{g} / \mathrm{mL}$ streptomycin at $37^{\circ} \mathrm{C}$ in a humidified atmosphere of $5 \% \mathrm{CO}_{2}$. All in vitro tests contain a vehicle control group ( $0.1 \%$ ethanol).

\section{Cell viability assay}

Cell viability was determined following a modification of the method reported previously [17]. Briefly, RAW264.7 cells were seeded on a 96-well plate $\left(1 \times 10^{4}\right.$ cells/well) in DMEM with $10 \%$ FBS, and then incubated for $24 \mathrm{~h}$. The cells were preincubated with BG10 $(0-100 \mu \mathrm{g} / \mathrm{mL})$ for $1 \mathrm{~h}$, stimulated by LPS $(1 \mu \mathrm{g} / \mathrm{mL})$ for $22 \mathrm{~h}$, and then further incubated with $200 \mu \mathrm{L}$ culture media containing $500 \mu \mathrm{g} / \mathrm{mL}$ MTT reagent for $2 \mathrm{~h}$. $100 \mu \mathrm{L}$ of DMSO was added to the plate after supernatnat was removed, and then incubated for $15 \mathrm{~min}$. Cell viability was determined at 570 $\mathrm{nm}$ using a micro-plate reader.

\section{Nitrite assay}

The amount of nitrite, an indicator of nitric monoxide (NO), was determined as described previously [23]. RAW264.7 cells were seeded on a 96-well plate and cultured. After $24 \mathrm{~h}$, the cells were preincubated with BG10 for $1 \mathrm{~h}$, and then stimulated with LPS for $23 \mathrm{~h}$. The amount of nitrite were measured using Griess reagent ( $1 \%$ sulfanilamide and $0.1 \%$ naphthylethylenediamine dihydrochloride in $2.5 \%$ phosphoric acid). $50 \mu \mathrm{L}$ of cell culture medium was mixed with $50 \mu \mathrm{L}$ of Griess reagent. Then, the mixture was incubated for $15 \mathrm{~min}$, and then the absorbance at $540 \mathrm{~nm}$ was measured using a micro-plate reader.

Enzyme-linked immunosorbent assay of IL- 6 and TNF- $a$

To measure the amounts of IL- 6 and TNF- $\alpha$ in cultured media all the cultured media were centrifuged, and then stored at $-80^{\circ} \mathrm{C}$ until use. IL- 6 and TNF- $\alpha$ were detected by ELISA kits according to the manufacturer's instructions.

Enzyme immunoassay analysis of $P G E_{2}$

To determine the level of $\mathrm{PGE}_{2}$ in cultured media, all cultured media were centrifuged, and stored at $-80^{\circ} \mathrm{C}$ until use. $\mathrm{PGE}_{2}$ was measured by EIA kits according to the manufacturer's instructions.

\section{Extraction of Nuclear and Cytosolic protein}

Nuclear and cytosolic proteins were performed following a process reported previously [23] with a Nuclear Extraction Kit from (Cayman Chemical Company, Inc., Ann Arbor, MI, USA). Nuclear and cytosolic proteins were fractionated according to the instructions of the manufacturer.

\section{Immunoblotting analysis}

Immunoblotting analysis was evaluated following the method reported previously [23]. PVDF membranes containing blotted proteins were visualized by WEST One ${ }^{\mathrm{TM}}$ western blot detection system (iNtRON Biotechnology, Inc., Seongnam, Korea). The level of target proteins was compared to that of a loading control ( $\beta$-actin or Lamin B), and the results were expressed as a ratio of density of each protein identified by a protein standard size marker (BIOFACT Co., Ltd., Daejeon, Korea). The density of each inverted band was measured using ImageJ software (version 1.50i for Windows; NIH, USA).

\section{Statistical analyses}

The experimental results were listed as means \pm SD or SEM. One-way analysis of variance (ANOVA) was used for multiple comparisons (GraphPad Prism version 5.03 for Windows, San Diego, CA, USA). If there was a significant variation between treated groups, the Dunnett test was applied. Differences at the ${ }^{*} P<0.05$ and ${ }^{* *} P<0.01$ levels were considered statistically significant.

\section{RESULTS}

Inhibitory effect of BG10 on TPA-induced contact dermatitis

First, we investigated whether BG10 attenuated TPA-induced contact dermatitis in mice, after we found that anti-allergic [16] and anti-septic properties [17] of ABG previously. TPA-induced dermatitis model is commonly used as the contact dermatitis model [22]. When mice were applied with TPA to ears, TPA induced an increment in ear edema in mice, whereas BG10 (0.5 $\mathrm{mg} / \mathrm{mL}$ ) significantly reduced the ear edema (Fig. 1C) without toxicity (Fig. 1A and 1B) in TPA-treated mice. In addition, BG10 significantly inhibited the formation of IL- 6 and TNF-a in TPA-treated ear tissues (Fig. 1D and 1E). These results indicate that BG10 possesses anti-dermatitic activity through inhibiting the production of inflammatory cytokines such as IL- 6 and TNFa. Therefore, BG10 may be used for treatment or prevention of contact dermatitis.

Inhibitory effects of BG10 on the formation of inflammatory mediators in LPS-activated macrophages

Since we found inhibitory effects of BG10 on the formation of inflammatory mediators in the TPA-induced dermatitis model, we further investigated effect of BG10 on LPS-activated macrophages. As shown in Fig. 2, BG10 at $\geq 25 \mu \mathrm{g} / \mathrm{mL}$ not only dramatically suppressed the formation of $\mathrm{NO}$ and IL-6 with IC value of $7.07 \mu \mathrm{g} / \mathrm{mL}$, but also dose-dependently inhibited that of TNF- $a$ with $\mathrm{IC}_{50}$ value of $52.07 \mu \mathrm{g} / \mathrm{mL}$ and $\mathrm{PGE}_{2}$ with $\mathrm{IC}_{50}$ value of $38.46 \mu \mathrm{g} / \mathrm{mL}$. Moreover, such effects of BG10 did not show any significant cytotoxicity (Fig. 3). Taken together, these findings suggest that BG10 regulates LPS-mediated inflammatory reaction through inhibiting the formation of inflammatory mediators in macrophages at non-cytotoxic concentrations. Therefore, the anti-dermatitic action of BG10 may be closely associated with the inhibition of LPS-activated macrophages.

Inhibitory effects of BG10 on expression of iNOS and COX-2

Next, we examined effects of BG10 on expression of iNOS, a NO synthase, and COX-2, a rate-limiting enzyme for prostaglandin biosynthesis, in LPS-stimulated macrophages and antioxidant activity of BG10, after we found the inhibition of BG10 on the formation of NO and PGE 2 . LPS-activated RAW264.7 cells elevated the expression of iNOS and COX-2, whereas BG10 significantly suppressed that of iNOS and COX-2 in the cells (Fig. 4A). Interestingly, BG10 at $100 \mu \mathrm{g} / \mathrm{mL}$ completely blocked the expression levels of iNOS and COX-2 as the levels of control 
(A)

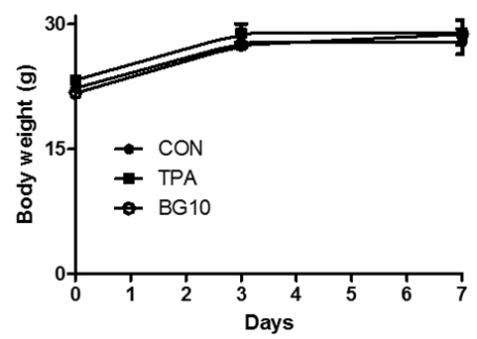

(C)

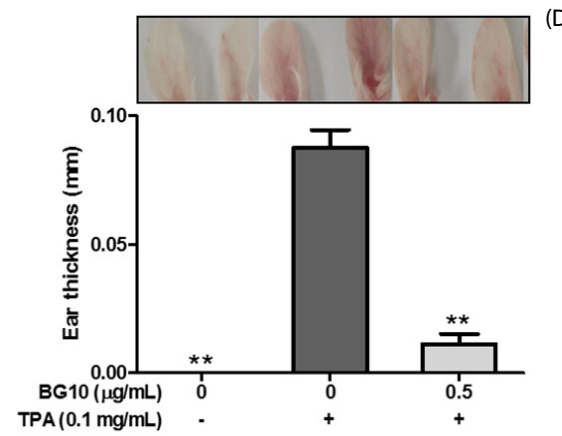

(B)

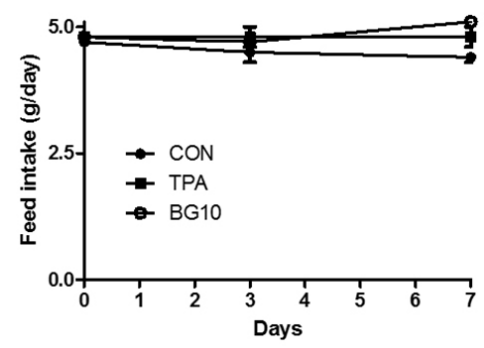

(D)

(E)
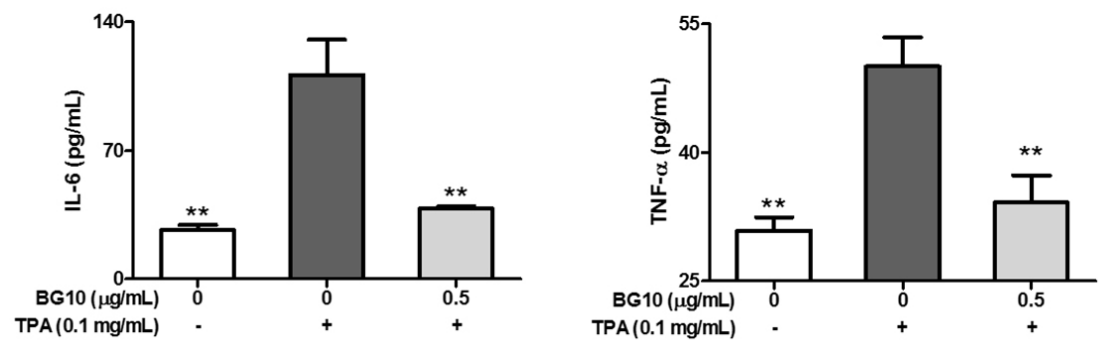

Fig. 1. Inhibitory effects of BG10 on TPA-induced dermatitis in mice. ICR mice were spread with BG10, a fraction of aged black garlic extract (0.5 mg/mL), on the back of ears prior to 12-O-tetradecanoylphorbol-13-acetate (TPA; $0.1 \mathrm{mg} / \mathrm{mL}$ ) challenge. Ear thickness, and the levels of IL-6 and TNF-a in ear tissues were determined as described in the Materials and Methods section. The data are expressed as the mean \pm SEM values of septuple determinations. ${ }^{* \star} P<0.01$ versus the TPA-treated group. A, body weight; B, food intake; $\mathrm{C}$, ear thickness; D, IL-6; E, TNF-a.

(A)

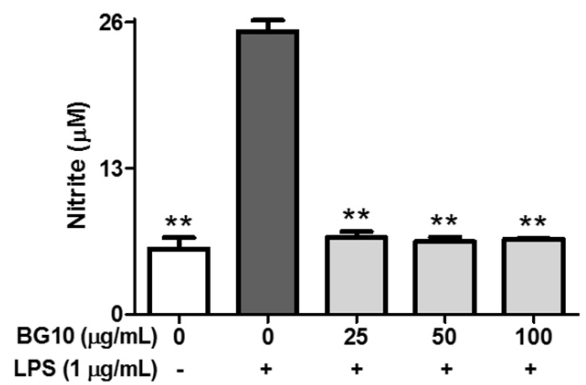

(C)

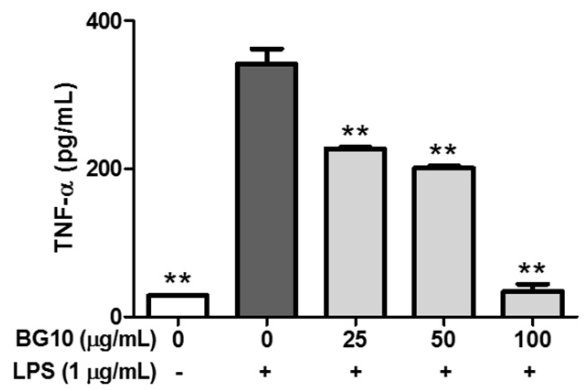

(B)

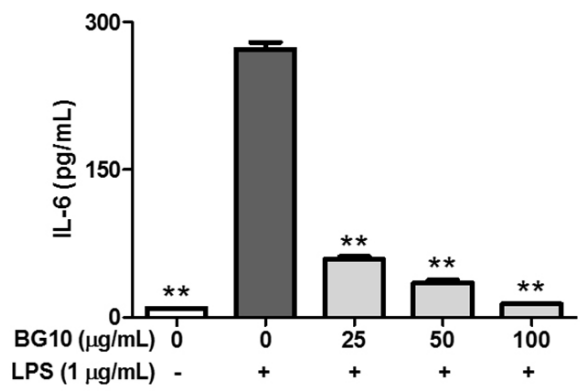

(D)

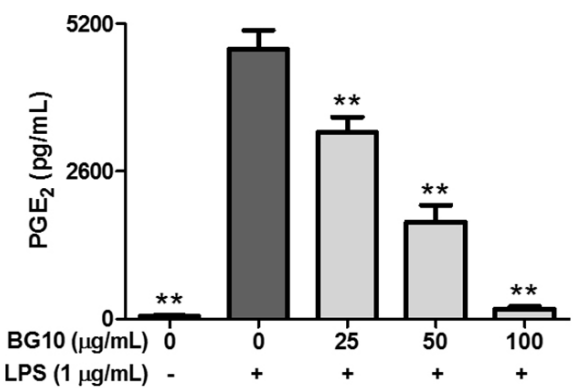

Fig. 2. Inhibitory effects of BG10 on the formation of NO, IL-6, TNF- $a$ and PGE 2 in LPS-activated RAW 264.7 cells. RAW 264.7 cells were seeded on 96-well plate (5 $\times$ $10^{4}$ cells/well) in DMEM with $10 \%$ FBS at $37^{\circ} \mathrm{C}$ overnight. The cells were simultaneously exposed to BG10 (0-100 $\left.\mu \mathrm{g} / \mathrm{mL}\right)$ with or without lipopolysaccharide (LPS; $\left.1 \mu \mathrm{g} / \mathrm{mL}\right)$ for $24 \mathrm{~h}$. The levels of NO, IL-6, TNF- $a$ and PGE 2 were determined as described in the Materials and Methods section. The data are expressed as the mean \pm SD values of triple determinations. ${ }^{\star}{ }^{*} P<0.01$ versus the LPS-treated group. A, NO; B, IL-6; C, TNF-a; D, PGE 2 .

group. Table. 1 summarizes the antioxidant activities of BG10. It suggests that BG10 possessing strong antioxidant activity directly inhibit the expression of iNOS and COX-2 in LPSactivated macrophages. Such effects of BG10 may be an important factor of its anti-dermatitic actions.
Regulatory effects of BG10 on nuclear translocation of $N F-k B$

Finally, we investigated that effect of BG10 on NF- $\kappa B$ translocation into nuclei in LPS-activated macrophages. The nuclear translocation of NF- $\kappa \mathrm{B}$ is associated with the formation of NO, inflammatory cytokines and eicosanoids in LPS-activated macrophages [24]. As shown in Fig. 4B, when RAW264.7 cells 


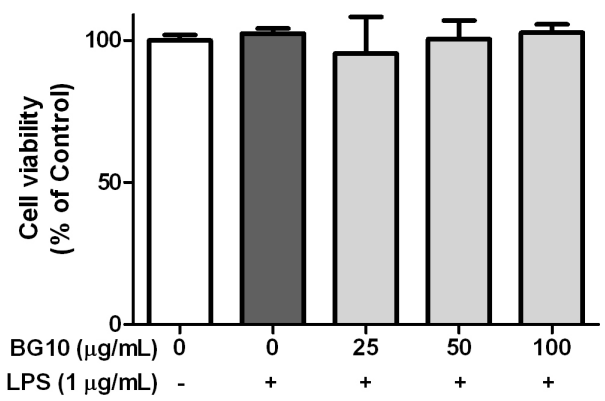

Fig. 3. Effect of BG10 on cell viability in LPS-activated RAW 264.7 cells. RAW 264.7 cells were seeded on 96-well plate in DMEM with $10 \%$ FBS at $37^{\circ} \mathrm{C}$ overnight The cells were simultaneously exposed to BG10 with or without LPS for $22 \mathrm{~h}$, and then further incubated with methyl thiazolyl tetrazolium (MTT) reagent $(500 \mu \mathrm{g} / \mathrm{mL})$ for $2 \mathrm{~h}$. Cell viability was determined as described in Materials and Methods section. The data are expressed as the mean $\pm S D$ values of quadruple determinations.

Table 1. Antioxidant activities of BG10

\begin{tabular}{lcc}
\hline \multirow{2}{*}{ Scavenging activity assays } & \multicolumn{2}{c}{ Scavenging capacity } \\
\cline { 2 - 3 } & BG10 & Vitamin C \\
\hline DPPH radical scavenging activity & $26.03 \pm 0.01(\%)$ & $72.57 \pm 0.43(\%)$ \\
Hydroxyl radical scavenging activity & $18.78 \pm 0.01(\%)$ & $75.92 \pm 1.17(\%)$ \\
ABTS radical scavenging activity & $10.24 \pm 0.04(\%)$ & $77.00 \pm 2.21(\%)$ \\
Ferric-reducing antioxidant power & $112.21 \pm 7.05(\mu \mathrm{M})$ & $274.87 \pm 4.42(\mu \mathrm{M})$ \\
\hline
\end{tabular}

Data are the mean \pm SD values of triple determinations.

were stimulated by LPS, they increased the nuclear level of NF- $\kappa$ $B$, and decreased the cytosolic levels of NF- $\kappa B$ and $I \kappa B a$. Contrastively, BG10 reduced the nuclear level of NF- $\kappa B$, and recovered the cytosolic levels of $\mathrm{NF}-\kappa \mathrm{B}$ and $\mathrm{I} \mathrm{BBa}$ dosedependently. Overall, it indicated that BG10 could directly inhibit the nuclear translocation of NF- $\mathrm{KB}$ in LPS-activated macrophages. The effect of BG10 may be another important

(A)
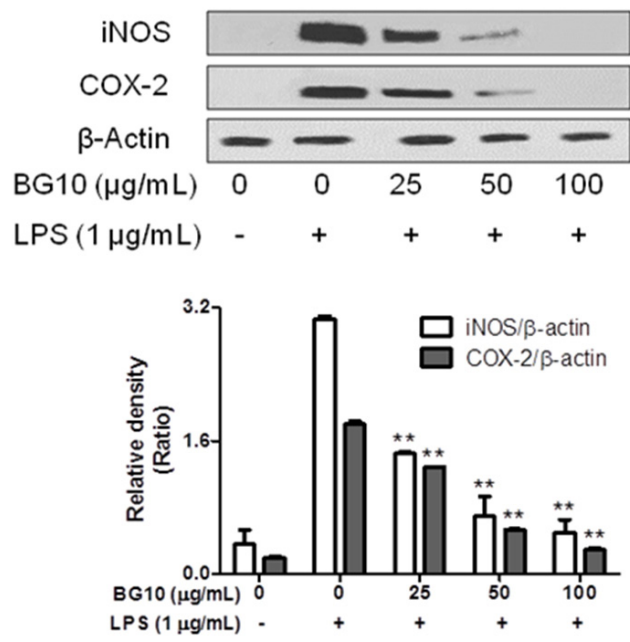

factor for its anti-dermatitic actions. Therefore, it suggests that BG10 possesses anti-dermatitic properties through directly downregulating the activation of NF- $\kappa B$ pathway in LPS-activated macrophages.

\section{DISCUSSION}

Garlic has been used as a spice and a component of traditional medicine in Northeast Asia for a long time, and known to possess various biological actions including antiarteriosclerosis, antibiotic, anti-cancer and anti-inflammation [5-7]. Although garlic has the various beneficial effects, the intake and application of garlic for a phytomedicine and a functional food have been always limited by its severe side effects including contact dermatitis $[10,11]$. In contrast, aged garlic has more beneficial effects than raw garlic, and its side effects is lower than that $[12,15]$. Recently, we reported that $A B G$, one of aged garlics, exerted both anti-allergic and antiseptic activities $[16,17]$. In addition, BG10 is stronger anti-allergic action than the crude extract of ABG [16]. Such effect of BG10 is associated with rich phenolic compounds and flavonoids [16]. Although phenolic compounds and flavonoids are well known to have antioxidant and anti-inflammatory properties [25], effect of BG10 on contact dermatitis remains unknown.

Herein, we demonstrated that BG10 has strong antioxidant activity, and anti-dermatitic actions through inhibiting activated macrophages. Such effects of BG10 are closely related with inhibiting the formation of inflammatory mediators such as NO, TNF- $a$, IL- 6 and PGE 2 in the cells. The inhibitory effects of BG10 on inflammatory mediator production are closely associated with the directly inhibition of iNOS, COX-2 and NF- $\mathrm{kB}$. Moreover, the anti-inflammatory actions of BG10 are more potent than the crude extract of $A B G$ [17]. It suggests that BG10 may be useful for treatment and prevention of contact dermatitis.

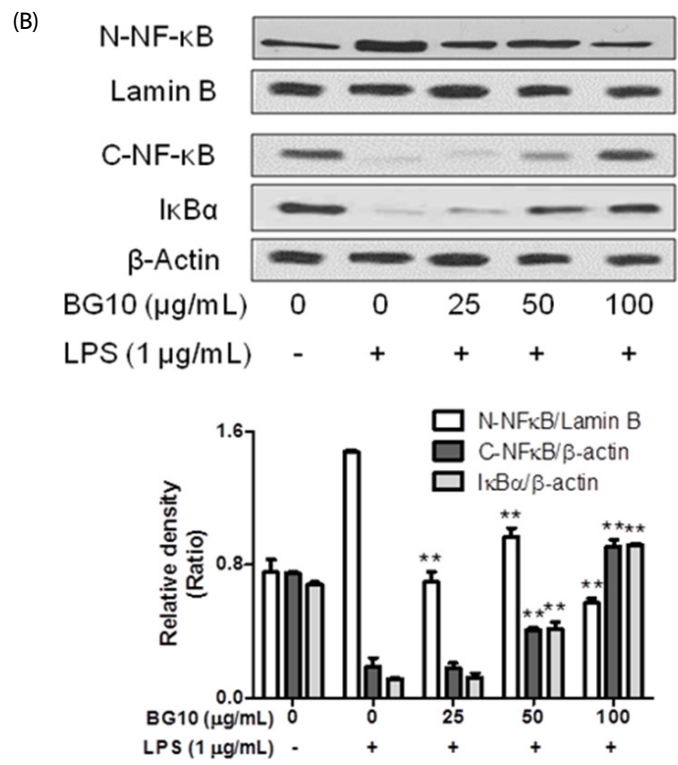

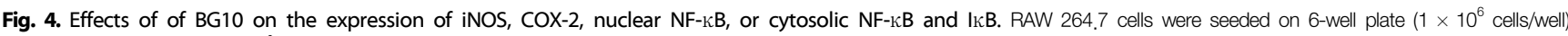
in DMEM with $10 \% \mathrm{FBS}$ at $37^{\circ} \mathrm{C}$ overnight. The cells were simultaneously exposed to BG10 with or without LPS for 15 min or $6 \mathrm{~h}$. They were washed, and then lysed in a cell lysis buffer. The expression of iNOS, COX-2 and nuclear NF-kB as well as cytosolic NF-kB and IkBa was determined as described in Materials and Methods section. Similar results were obtained in three independent experiments. ${ }^{\star \star} P<0.01$ versus LPS-treated group. A, iNOS and COX-2; B, nuclear NF-kB, cytosolic NF-kB and cytosolic IkBa. 
Concerning the mechanism for anti-inflammatory actions of BG10, one possible mechanism may be related to a direct suppression of activation toll-like receptor 4 (TLR4) signaling cascade in macrophages. Various immune cells including macrophages are found in the inflammatory tissue lesion in contact dermatitis [1]. Especially, macrophages are well known as be associated with chronic inflammatory diseases because they express TLR4 located on the plasma membrane $[24,26]$. When TLR4 is combined with LPS-endotoxin binding protein complex (LPS-binding protein, the cluster differentiation antigen14 and the myeloid differentiation protein-2), TLR4 activates myeloid differentiation factor 88 (MyD88) [26]. Then, the activated MyD88 leads to produce various inflammatory mediators such as IL-6, TNF- $\alpha$ and PGE $_{2}$ through NF- $\kappa B$ translocation into nucleus by the activation of mitogen- activated protein kinases (MAPKs) [26]. Moreover, the released inflammatory mediators cause severe or chronic inflammatory responses through recruiting other immune cells [24]. Therefore, NF- $\kappa B$ activation in LPS-activated macrophages is an important intracellular signaling mediator in early signaling pathway of TLR4 signaling cascades. In support of this, BG10 not only reduced nuclear $\mathrm{NF}-\kappa \mathrm{B}$ level, but also increased the cytosolic levels of NF- $\kappa \mathrm{B}$ and I $\mathrm{B}$ in LPS-activated RAW264.7 cells. In addition, BG10 also inhibited the expression of iNOS and COX-2, which belong to down-stream proteins of TLR4 signaling cascade. Subsequently, BG10 suppressed the formation of NO, IL- 6 and TNF- $a$ in LPS-activated RAW264.7 cells and TPA-mediated dermatitis in mice. Taken together, it suggests that anti-dermatitic activity of BG10 is correlated with the direct inhibition of $1 \kappa B$ kinase (IKK) and/or NF- $\kappa \mathrm{B}$ translocation in activated macrophages.

Another possible mechanism may be correlated with antioxidant activity of BG10. LPS-activated macrophages can produce NO and ROS [23,24]. In addition, inflammatory cytokines, chemicals and ultraviolet radiation are able to induce the generation of NO and ROS in skin tissues [27,28]. Moreover, the NO and ROS are capable of inducing inflammation and apoptosis in skin tissues [28]. Therefore, the regulation of NO and ROS production in immune cells and skin tissues is another important event for anti-dermatitic action of BG10. Actually, the crude extract of $A B G$ exerts antioxidant activity through elevating the expression of antioxidant enzymes such as heme oxygenase-1 in LPS-activated macrophages $[17,29]$. In our data, BG10 itself showed strong antioxidant activity. The antioxidant activity of BG10 may be associated with its components such as phenolic compounds and flavonoids [16]. Although garlic and ABG include rich sulfur compounds such as diallyl sulfide, diallyl disulfide and diallyl trisulfide, the sulfur compounds are not able to inhibit allergic response in IgE/antigen-activated mast cells [16]. Separately, in previous report, when mice were orally administrated with BG10 form 33.3 to $66.7 \mathrm{mg} / \mathrm{kg}$, BG10 showed anti-allergic action in mice [16]. The concentrations are equal to 2.7 to $5.4 \mathrm{mg} / \mathrm{kg}$ (162.0 to $324.0 \mathrm{mg} / 60 \mathrm{~kg}$ ) in human based on body surface area [30]. Overall, it suggests that anti-dermatitic action of BG10 attenuates dermatitis through down-regulating oxidative stress in immune cells and skin tissues.

In conclusion, this study demonstrates that BG10 exerting anti-allergic activity possesses both antioxidant activity and anti-inflammatory actions in in vitro and in vivo. These findings reveal a novel feature of BG10 in LPS-mediated inflammation and TPA-induced dermatitis. The mechanisms for its antiinflammatory actions may include multiple targets such as IKK, iNOS, COX-2 and NF- $k$ B. Such effects may be due to rich phenolic compounds and flavonoids in BG10, and may provide further information for the application of BG10 as a phytomedicine and a functional food for therapies of inflammatory diseases including contact dermatitis.

\section{CONFLICT OF INTEREST}

The authors declare no potential conflicts of interests.

\section{ORCID}

Jae-Myung Yoo: https://orcid.org/0000-0002-3924-6919

Bo Ram You: https://orcid.org/0000-0002-3550-4175

Seong Yeon Baek: https://orcid.org/0000-0002-6372-2989

Mee Ree Kim: https//orcid.org/0000-0003-3813-1447

\section{REFERENCES}

1. Dhingra N, Gulati N, Guttman-Yassky E. Mechanisms of contact sensitization offer insights into the role of barrier defects vs. intrinsic immune abnormalities as drivers of atopic dermatitis. J Invest Dermatol 2013;133:2311-4.

2. Pérez-Pimiento AJ, Santaolalla $M$, de Paz $S$, Fernández-Parra $B$, Domínguez-Lázaro AR, Moneo I. Anaphylactic reaction to young garlic. Allergy 1999;54:626-9.

3. Itoh T, Ohguchi K, linuma M, Nozawa Y, Akao Y. Inhibitory effect of xanthones isolated from the pericarp of Garcinia mangostana L. on rat basophilic leukemia RBL-2H3 cell degranulation. Bioorg Med Chem 2008;16:4500-8.

4. Gilfillan AM, Tkaczyk C. Integrated signalling pathways for mast-cell activation. Nat Rev Immunol 2006;6:218-30.

5. Butt MS, Sultan MT, Butt MS, Iqbal J. Garlic: nature's protection against physiological threats. Crit Rev Food Sci Nutr 2009;49:538-51.

6. Liu CT, Sheen LY, Lii CK. Does garlic have a role as an antidiabetic agent? Mol Nutr Food Res 2007;51:1353-64.

7. Thomson M, Ali M. Garlic [Allium sativum]: a review of its potential use as an anti-cancer agent. Curr Cancer Drug Targets 2003;3:67-81.

8. Amagase $H$, Petesch $B L$, Matsuura $H$, Kasuga $S$, Itakura $Y$. Intake of garlic and its bioactive components. J Nutr 2001;131:955S-62S.

9. Lanzotti V. The analysis of onion and garlic. J Chromatogr A 2006;1112:3-22.

10. Borrelli F, Capasso R, Izzo AA. Garlic (Allium sativum L.): adverse effects and drug interactions in humans. Mol Nutr Food Res 2007;51:1386-97.

11. Burden AD, Wilkinson SM, Beck MH, Chalmers RJ. Garlic-induced systemic contact dermatitis. Contact Dermat 1994;30:299-300.

12. Moriguchi $\mathrm{T}$, Saito $\mathrm{H}$, Nishiyama $\mathrm{N}$. Anti-ageing effect of aged garlic extract in the inbred brain atrophy mouse model. Clin Exp Pharmacol Physiol 1997;24:235-42.

13. Banerjee SK, Mukherjee PK, Maulik SK. Garlic as an antioxidant: the good, the bad and the ugly. Phytother Res 2003;17:97-106.

14. Bae SH, Lee SW, Kim MR, Kim JM, Suh HJ. Influence of steeping solution and storage temperature on the color change of garlic. 
J Food Sci 2010;75:C108-12.

15. Imai J, Ide N, Nagae S, Moriguchi T, Matsuura H, Itakura Y. Antioxidant and radical scavenging effects of aged garlic extract and its constituents. Planta Med 1994;60:417-20.

16. Yoo JM, Sok DE, Kim MR. Anti-allergic action of aged black garlic extract in RBL-2H3 cells and passive cutaneous anaphylaxis reaction in mice. J Med Food 2014;17:92-102.

17. Kim MJ, Yoo YC, Kim HJ, Shin SK, Sohn EJ, Min AY, Sung NY, Kim MR. Aged black garlic exerts anti-inflammatory effects by decreasing no and proinflammatory cytokine production with less cytoxicity in LPS-stimulated raw 264.7 macrophages and LPS-induced septicemia mice. J Med Food 2014;17:1057-63.

18. Nencini C, Menchiari A, Franchi GG, Micheli L. In vitro antioxidant activity of aged extracts of some Italian Allium species. Plant Foods Hum Nutr 2011;66:11-6.

19. Raschke WC, Baird S, Ralph P, Nakoinz I. Functional macrophage cell lines transformed by Abelson leukemia virus. Cell 1978;15:261-7.

20. Birasuren B, Kim NY, Jeon HL, Kim MR. Evaluation of the antioxidant capacity and phenolic content of agriophyllum pungens seed extracts from Mongolia. Prev Nutr Food Sci 2013;18:188-95.

21. Schwartz JN, Daniels CA, Shivers JC, Klintworth GK. Experimental cytomegalovirus ophthalmitis. Am J Pathol 1974;77:477-92.

22. Fowler AJ, Sheu MY, Schmuth M, Kao J, Fluhr JW, Rhein L, Collins JL, Willson TM, Mangelsdorf DJ, Elias PM, Feingold KR. Liver X receptor activators display anti-inflammatory activity in irritant and allergic contact dermatitis models: liver-X-receptor-specific inhibition of inflammation and primary cytokine production. J Invest Dermatol 2003;120:246-55.

23. Jeon HL, Yoo JM, Lee BD, Lee SJ, Sohn EJ, Kim MR. Antiinflammatory and antioxidant actions of $\mathrm{N}$-arachidonoyl serotonin in RAW264.7 cells. Pharmacology 2016;97:195-206.

24. Hamidzadeh K, Christensen SM, Dalby E, Chandrasekaran P, Mosser DM. Macrophages and the recovery from acute and chronic inflammation. Annu Rev Physiol 2017;79:567-92.

25. Upadhyay S, Dixit M. Role of polyphenols and other phytochemicals on molecular signaling. Oxid Med Cell Longev 2015;2015:504253.

26. O'Neill LA. Toll-like receptor signal transduction and the tailoring of innate immunity: a role for Mal? Trends Immunol 2002;23: 296-300.

27. Seo SH, Jeong GS. Fisetin inhibits TNF-a-induced inflammatory action and hydrogen peroxide-induced oxidative damage in human keratinocyte HaCaT cells through PI3K/AKT/Nrf-2-mediated heme oxygenase-1 expression. Int Immunopharmacol 2015;29:246-53.

28. Bito T, Nishigori C. Impact of reactive oxygen species on keratinocyte signaling pathways. J Dermatol Sci 2012;68:3-8.

29. Park HJ, Jeon BT, Kim HC, Roh GS, Shin JH, Sung NJ, Han J, Kang D. Aged red garlic extract reduces lipopolysaccharide-induced nitric oxide production in RAW 264.7 macrophages and acute pulmonary inflammation through haeme oxygenase-1 induction. Acta Physiol (Oxf) 2012;205:61-70.

30. Nair $A B$, Jacob S. A simple practice guide for dose conversion between animals and human. J Basic Clin Pharm 2016;7:27-31. 